\title{
Modeling materials flow of waste concrete from construction and demolition wastes in Taiwan
}

\author{
T.Y.Hsiao ${ }^{\text {a,* }}$, Y.T. Huang a , Y.H. Yu ${ }^{\text {a }}$, I.K. Wernick ${ }^{\text {b }}$ \\ ${ }^{a}$ Graduate Institute of Environmental Engineering, National Taiwan University, Room 311, 71, Chou Shan Road, Taipei 10660 Taiwan \\ ${ }^{\mathrm{b}}$ Columbia University, New York, NY 10027, USA
}

Received 20 May 2002; received in revised form 2 October 2002; accepted 27 December 2002

\begin{abstract}
Material flows of concrete from construction and demolition (C\&D) waste in Taiwan have grown considerably over the last two decades, Hsiao et al. (2001). This increased flow puts pressure on limited national disposal capacity and has indirectly caused ecological damage to domestic riparian zones used as sources of natural aggregate. Using existing statistics and literature sources for C\&D waste generation in Taiwan we have developed a dynamic model of domestic material flows of concrete waste and employ statistical analyses to obtain projections of future material flows. Our major findings are: (1) Taiwan's rate of waste concrete generation in 2001 for the residential and commercial construction industry was approximately 2.4 Million Metric Tons (MMT) per year, averaging 0.11 metric tons of waste concrete generated annually by each Taiwanese; (2) Around the year 2009, the national rate will more than triple to exceed the spike in C\&D concrete waste generation that occurred after the Chi Chi earthquake 9/21/99, 8.5 MMT. (3) Aside from pilot-scale development of waste concrete utilization technology, nationwide recycling rates remain negligible. Without resource recovery, the volume of C\&D waste generation by 2009 is projected to occupy nearly $7 \%$ of all existing and planned domestic landfill capacity. A target is established to raise resource recovery rates for waste concrete to $50 \%$ by 2005 and a $100 \%$ nationwide recycling rate by 2009 .
\end{abstract}

(C) 2003 Elsevier Science Ltd. All rights reserved.

Keywords: Material flows; Construction and demolition waste; Waste concrete; Recycling; Dynamic modeling

\section{Nomenclature}

$W_{C} \quad$ generation of waste concrete from construction, in tons

$W_{D} \quad$ generation of waste concrete from demolition, in tons

$d_{c c} \quad$ specific gravity of construction waste concrete, 1.8 , in tons/ $\mathrm{m}^{3}$ (Poon, 1997)

$d_{c d} \quad$ specific gravity of demolition waste concrete, 2.2 , in tons $/ \mathrm{m}^{3}$ (Chen, 1996)

$A_{i j} \quad$ total floor area on use permits built for type $\mathrm{i}$ construction and type $\mathrm{j}$ purpose, in $\mathrm{m}^{2}$

$F c_{i} \quad$ volume of wastes per unit floor area on construction for type i construction, in $\mathrm{m}^{3} / \mathrm{m}^{2}$

$P c_{c} \quad$ percentage of waste concrete in construction wastes, 21.17\% (Architecture and Building Research Institute (ABRI), Taiwan Ministry of Interior, 1998b)

$A_{D}(t+N)$ total floor area (as shown on demolition permits) demolished in year $t+N$, in $\mathrm{m}^{2}$

$A c(t)$ total floor area (as shown on construction permits) built in year $t$, in $\mathrm{m}^{2}$

\footnotetext{
* Corresponding author. Tel.: + 886-2-23929964; fax: +886-223628043.

E-mail address: f5541021@ms.cc.ntu.edu.tw (T.Y. Hsiao).
} 


\section{Introduction}

Taiwan faces several environmental impacts resulting from the material flow of C\&D materials. On the input side, demand for natural aggregate in domestic construction has led to both legal and illegal excavation practices that have impacted riparian zones across Taiwan in the last decades. On the output side, the volume of C\&D waste generation threatens to rapidly absorb the projected landfill capacity of this densely populated nation.

Inputs of construction aggregates to the Taiwan economy represent by far the most voluminous domestic mined resource. Until the late 1990s, more than $90 \%$ of the aggregate supply was extracted from domestic riverbeds and banks. Years of digging have left ecological damage and a depleted reserve base as a legacy (Chen, 1998). Government efforts to protect riparian zones by limiting the area available for aggregate mining have rendered this domestic source scarce. Nonetheless, continued unauthorized extraction causes severe erosion of riverbeds and infrastructure.

Because of its high population density, the limited availability of treatment sites for C\&D waste in Taiwan poses a problem as this nation enters successive generations of industrial development. Projects in Taiwan are underway for re-utilizing waste concrete and brick to develop commercial concrete bricks for construction, however, these projects remain in the development stage (ABRI, 2000). As national landfill capacity becomes scarce, the huge volume of $C \& D$ waste threatens to overwhelm both existing and planned capacity.

To address the problems of both inputs and outputs of construction aggregates in Taiwan we draw on the model of Industrial Ecology (Wernick and Ausubel, 1997). First, we target the production, use, disposal, and recycling of concrete in Taiwan to quantify the material flows of construction aggregates and determine the economic factors influencing production and waste generation. Second, we identify systemic changes that can foster greater resource recovery and reduce environmental pressures over the life cycle. We draw on multiple studies examining the technical and economic considerations for a robust concrete recycling system (Kelly, 1998; Wilburn and Goonan, 1998).

The Taiwanese government has already begun several institutional initiatives to address the problems posed by $\mathrm{C} \& \mathrm{D}$ wastes. In addition to government-sponsored programs for developing commercial products from construction waste, the Taiwan Environmental Protection Administration initiated the waste asphalt concrete reutilization program in 1999 to standardize relevant quality requirements and has established the Remaining Earthwork Information Service Center (ABRI, 2000; Bureau of Mines, Taiwan Ministry of Economics Affairs (MOEA), 1999). These efforts offer promise for reduc- ing some large flows of waste material but their effect will require time to identify in the data.

\section{Methodology}

\section{Definition of construction waste by type and source}

Construction wastes are defined as all wastes generated in construction works, including remaining mud, sand, stone, dirt (including remaining volume of earthwork), brick, tile, concrete, asphalt concrete, timber, bamboo, paper, glass, pottery and porcelain, plastic, and metal, but not including general office and residential wastes (refuse, kitchen waste and excretions). Construction works include all building and civil works in new projects, renovations, additions, rebuilding, repair and demolitions. Sources of construction wastes are defined as in Fig. 1.

Building construction is defined as work done on newly built, added, renovated, or repaired structures that by law require a construction permit before work begins and a use permit after their completion (Construction and Planning Administration (CPA), Taiwan Ministry of Interior, 2001). Construction is defined as Legal and Illegal construction activities encompassing new construction, addition, renovation, rebuilding, and repair as well as the associated demolition. Demolition is defined as Legal reported demolition, Demolition of structures under government requisition, Demolition of structures destroyed by natural force, Demolition of illegal structures, and Illegal demolition. Civil construction is considered a separate category including private and public civil works (Architecture and Building Research Institute (ABRI), Taiwan Ministry of Interior, 1998a).

C\&D wastes from Illegal activities and civil construction are not considered here. Though the illegal excavation of natural aggregates continues to be a problem in Taiwan, C\&D waste generation from illegal activities is estimated to constitute a small fraction $(<5 \%)$ of those generated by legal activities. No credible data were available for $\mathrm{C} \& \mathrm{D}$ waste from private and public civil works, however estimated demand for concrete for civil works is approximately $2 / 3$ the demand for building construction (Wei and Tan, 1999). Because the lifetime of civil works structures generally exceeds those for residential and commercial building, the amount of annual C\&D waste from civil works is likely less than this fraction of concrete waste from other construction. We estimate that actual annual waste concrete generation might be $\geq 50 \%$ higher than the results presented here to include the contribution from civil construction. Future research will attempt to provide greater accuracy for the waste concrete generation from civil works. 


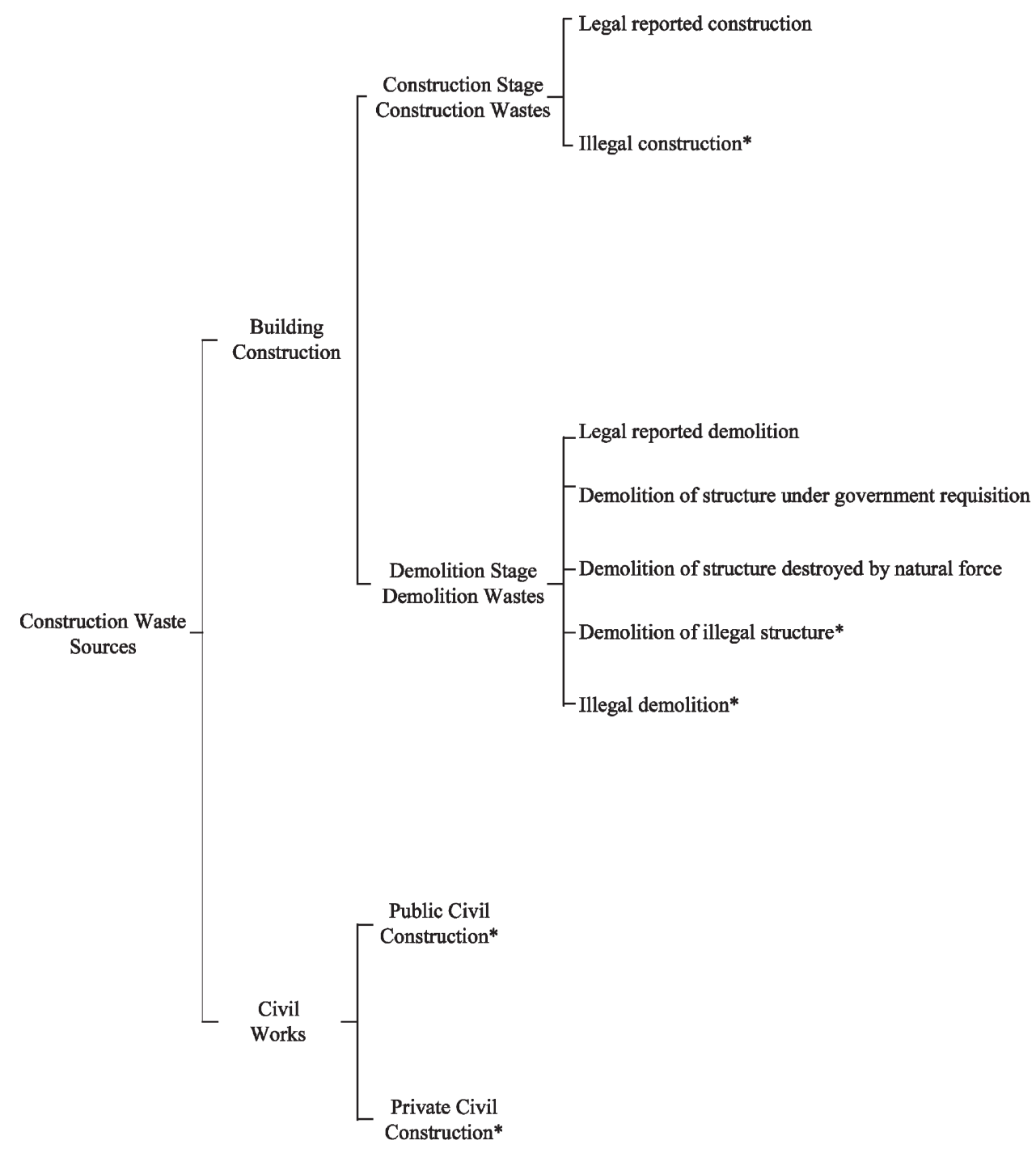

* Not considered here

Fig. 1. Construction wastes by source.

The waste concrete output estimation model

Fig. 2 shows the analytic framework used for this study.

Because of the paucity of data on C\&D waste in Taiwan we built a model to estimate the relevant values. We use the concrete waste estimates generated from the unit area built or demolished as in Eq. (1) (Architecture and Building Research Institute (ABRI), Taiwan Ministry of Interior, 1998a).

$$
\begin{aligned}
& \boldsymbol{W}_{\mathbf{C}}=d_{c c} \times\left(\sum A_{i j} \times F_{c i}\right) \times P c_{c} \\
& \boldsymbol{W}_{\mathbf{D}}=d_{c d} \times \sum A_{i j} \times F_{c i}
\end{aligned}
$$

Data on waste generation per unit area is used in combination with data on the floor area for which construction and demolition permits were issued to arrive at national values for total $C \& D$ waste generation. Table 1 shows the total floor space for which construction and demolition permits were issued in Taiwan from 19851999. Based on the annual data for floor area we employ an iterative model to predict future trends employing MINITAB software.

Because annual data for the floor area for demolition permits are limited to 1999 , we are unable to employ the model for demolition to predict future trends. As a result, the waste concrete generated from demolition is estimated based on the demolition ratio, defined as:

Demolition Ratio $(D R)=A_{D}(t+N) / A c(t)$

If $A c\left(t_{0}\right)$ for year $t_{0}$ is available, we can estimate $A_{D}\left(t_{0}+N\right)$ at year $t_{0}+N$ using Eq. (3).

$A_{D}\left(t_{0}+N\right)=A c\left(t_{0}\right) \times\left[A_{D}(t+N) / A c(t)\right]$

Using a time horizon of $N=28$ years for the life of 


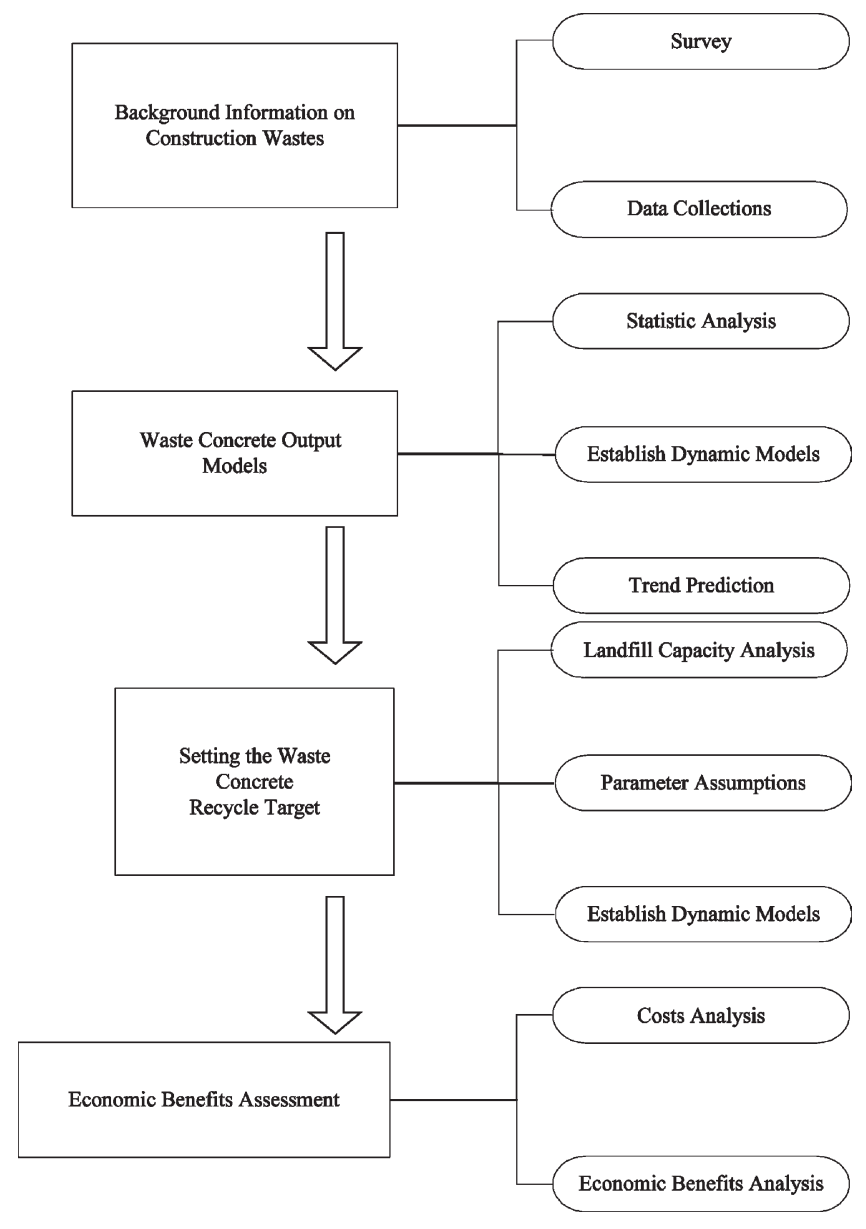

Fig. 2. Study framework.

Table 1

Total floor area for construction and demolition permits in Taiwan from 1985-1999

\begin{tabular}{lll}
\hline Year & $\begin{array}{l}\text { The total floor area for } \\
\text { construction permits }\left(\mathrm{m}^{2}\right)\end{array}$ & $\begin{array}{l}\text { The total floor area for } \\
\text { demolition permits }\left(\mathrm{m}^{2}\right)\end{array}$ \\
\hline 1985 & $28,114,894$ & - \\
1986 & $25,974,720$ & - \\
1987 & $25,167,539$ & - \\
1988 & $29,607,797$ & - \\
1989 & $31,234,036$ & - \\
1990 & $31,271,059$ & - \\
1991 & $31,995,034$ & - \\
1992 & $36,922,351$ & - \\
1993 & $47,542,986$ & - \\
1994 & $58,159,322$ & - \\
1995 & $55,262,803$ & - \\
1996 & $45,709,423$ & - \\
1997 & $38,462,486$ & - \\
1998 & $38,683,334$ & - \\
1999 & $41,239,986$ & $1,563,723$ \\
\hline
\end{tabular}

a built structure, we calculate a demolition ratio of $15.33 \%$.

Table 2 shows the calculated volume and ratio of waste concrete per unit area of construction and is used in Eq. (1) to estimate concrete waste from building construction in Taiwan from 1985-1999 (Architecture and Building Research Institute (ABRI), Taiwan Ministry of Interior, 1998b \& 1999). For a comprehensive review of the data used here by type of construction, see data notes in Appendix A.

Using the model we find that the generation of waste concrete from construction has a cycle of approximately 14 years with an overall trend of increase, as shown in Fig. 3. The year 2001 represents a low in the cycle with annual generation of approximately 2.4 MMT. By the year 2009, the output of waste concrete is expected to reach a cyclical peak of 8.5 MMT/year, representing $\sim 350 \%$ growth above current rates and approximating the quantity generated by the $9 / 21 / 99$ earthquake.

Fig. 4 shows historical and projected waste concrete generation from demolition in Taiwan from 1999-2011.

\section{Setting a waste concrete recycling target}

Given the data for projected C\&D waste generation and the data on regional landfill capacity in Taiwan we use a dynamic model to set a reasonable waste concrete recycle target for each target year and target area in Taiwan looking a decade into the future. The Carrying Capacity Ratio (CR), is defined as the ratio of the weight of generated waste concrete to remaining regional landfill capacity. The Recycle Target Rate (RT) is defined as:

$$
\begin{array}{lll}
\text { For } & 0 \leq \mathrm{CR} \leq 1 & \mathrm{RT}=\mathrm{CR}^{2} \times 100 \% \\
\text { For } & 1<\mathrm{CR} & \mathrm{RT}=100 \%
\end{array}
$$

Total landfill capacity includes existing capacity as well as capacity under construction. The model for estimating RT uses STELLA software v. 6.0.1, as shown in Fig. 5, see Appendix B.

Fig. 6 shows the results of the model for the years 2001-2011. The model suggests that all areas should begin implementing waste concrete recovery programs as soon as possible. Long term, the model predicts that the target rate for recycling should reach $50 \%$ by year 2005 and $100 \%$ by 2009 to avoid overloading existing and projected capacity.

\section{Economic benefit assessment of waste concrete recycling}

To examine the feasibility of widespread waste concrete resource recovery and implementing the recycling targets discussed above, we performed an economic 
Table 2

Construction waste volumes from unit floor area by material

\begin{tabular}{|c|c|c|c|c|c|c|c|c|}
\hline \multirow[t]{2}{*}{ Structure (i) } & \multirow[t]{2}{*}{ Purpose (j) } & \multicolumn{7}{|c|}{$\begin{array}{l}\text { Materials types } \\
\text { Principal materials of structure } \longrightarrow \longrightarrow \longrightarrow \longrightarrow \longrightarrow \longrightarrow \longrightarrow \rightarrow \text { Fix up materials }\end{array}$} \\
\hline & & $\begin{array}{l}\text { Steels } \\
\left(\mathrm{m}^{3} / \mathrm{m}^{2}\right)\end{array}$ & $\begin{array}{l}\text { Concrete } \\
\left(\mathrm{m}^{3} / \mathrm{m}^{2}\right)\end{array}$ & $\begin{array}{l}\text { Brick } \\
\left(\mathrm{m}^{3} / \mathrm{m}^{2}\right)\end{array}$ & $\begin{array}{l}\text { Non-ferrous } \\
\text { metals } \\
\left(\mathrm{m}^{3} / \mathrm{m}^{2}\right)\end{array}$ & $\begin{array}{l}\text { Glass } \\
\left(\mathrm{m}^{3} / \mathrm{m}^{2}\right)\end{array}$ & $\begin{array}{l}\text { Wood } \\
\left(\mathrm{m}^{3} / \mathrm{m}^{2}\right)\end{array}$ & $\begin{array}{l}\text { Total } \\
\left(\mathrm{m}^{3} / \mathrm{m}^{2}\right)\end{array}$ \\
\hline \multirow[t]{5}{*}{$\mathrm{RC}$} & Dwelling & 0.0117 & 0.6010 & 0.0705 & 0.0002 & 0.0008 & 0.03 & 0.7142 \\
\hline & Factory & 0.1150 & 0.5360 & 0.0585 & 0.0036 & 0.0009 & 0.03 & 0.6404 \\
\hline & Office & 0.0159 & 0.6360 & 0.0571 & 0.0002 & 0.0006 & 0.03 & 0.7398 \\
\hline & School & 0.0135 & 0.6670 & 0.1029 & 0.0003 & 0.0008 & 0.03 & 0.8045 \\
\hline & Average & 0.0132 & 0.6100 & 0.0723 & 0.0011 & 0.0008 & 0.03 & 0.7274 \\
\hline Steel & & 0.0210 & 0.2107 & 0.0585 & 0.0036 & 0.0009 & 0.03 & 0.3247 \\
\hline Brick & & 0.0000 & 0.0000 & 0.4800 & 0.0002 & 0.0008 & 0.20 & 0.6810 \\
\hline Strength brick & & 0.0027 & 0.3200 & 0.4000 & 0.0002 & 0.0008 & 0.32 & 1.0437 \\
\hline Wood & & 0.0000 & 0.0000 & 0.0500 & 0.0002 & 0.0008 & 0.80 & 0.8510 \\
\hline Others & & 0.0074 & 0.2281 & 0.2122 & 0.0011 & 0.0008 & 0.276 & 0.7256 \\
\hline
\end{tabular}

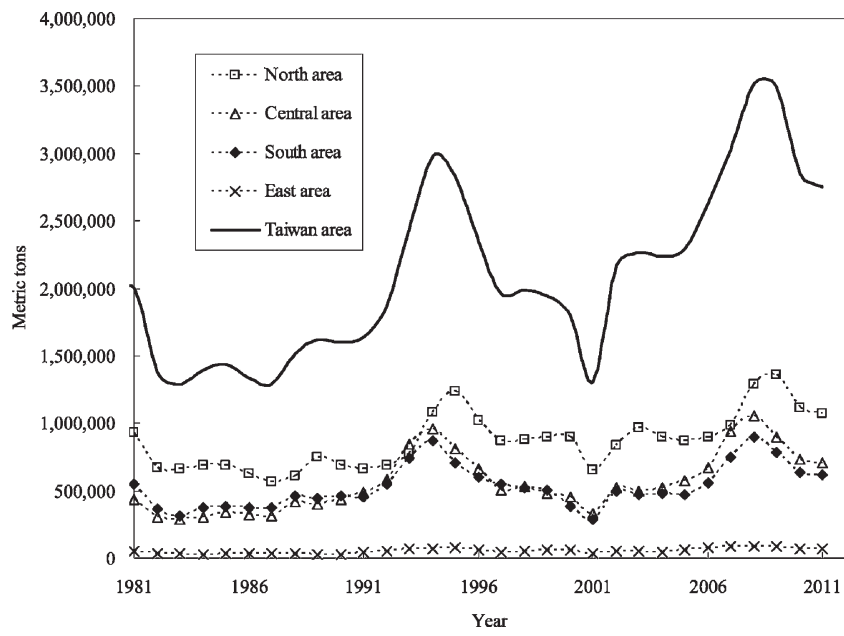

Fig. 3. Waste concrete output from construction in Taiwan from 1981-2011.

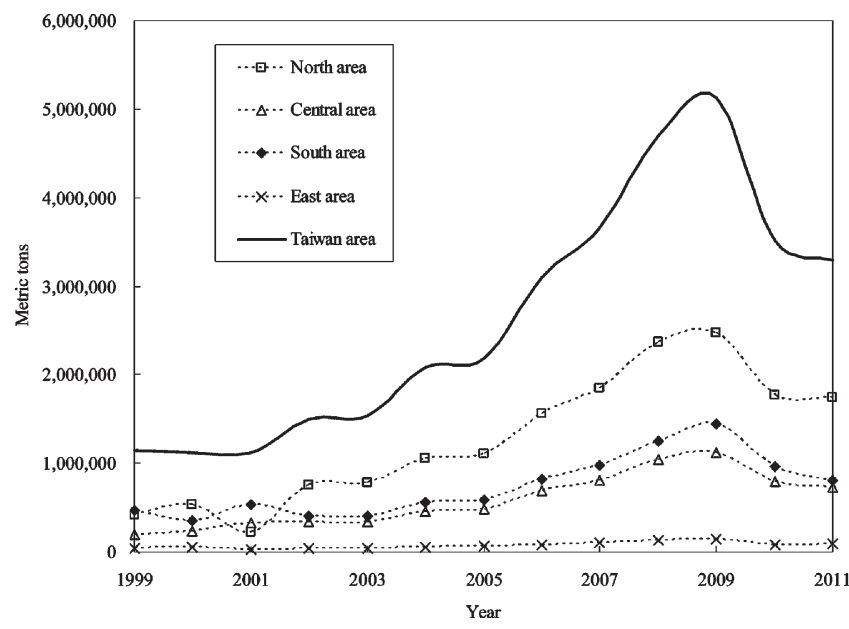

Fig. 4. Waste concrete output from demolition in Taiwan from 19992011. benefit assessment for each Taiwanese region. We compared the cost of non-recycling to that of recycling to estimate the net economic impact of recycling waste concrete for each area.

Specifically, for an equivalent volume of material, we set economic benefit equal to:

1. The total cost incurred from transporting waste concrete to the final treatment site +

2. Direct cost incurred of using natural aggregate -

3 . The total cost of recycling and reusing the waste concrete $=$

The economic benefits for recycling waste concrete.

As shown in Table 3, waste concrete recycling provides economic benefit. Using a recycling rate of $32.5 \%$, our model suggests that recycling waste concrete could generate over US\$3.5M nationally in Taiwan. If the waste concrete projected for 2009 were entirely recycled, the economic benefit would exceed US\$11.7M.

\section{Conclusion}

Based on our analysis, the output of waste concrete from $C \& D$ waste in Taiwan will continue to grow unevenly but steadily over the next decade. Left unchecked, annual output in the year 2009, will reach 8.5 MMT/year, approximately the same quantity generated by the 9/21/99 earthquake. To reduce pressures on domestic sources of natural aggregates as well as limited landfill capacity, we propose the development of a national waste concrete recycling infrastructure.

This study suggests that all regions in Taiwan introduce measures to enable better management of waste concrete resources. As management targets, recycling rates of $50 \%$ by 2005 and $100 \%$ by 2009 are necessary to avoid overloading landfill capacities in all regions of Taiwan. 

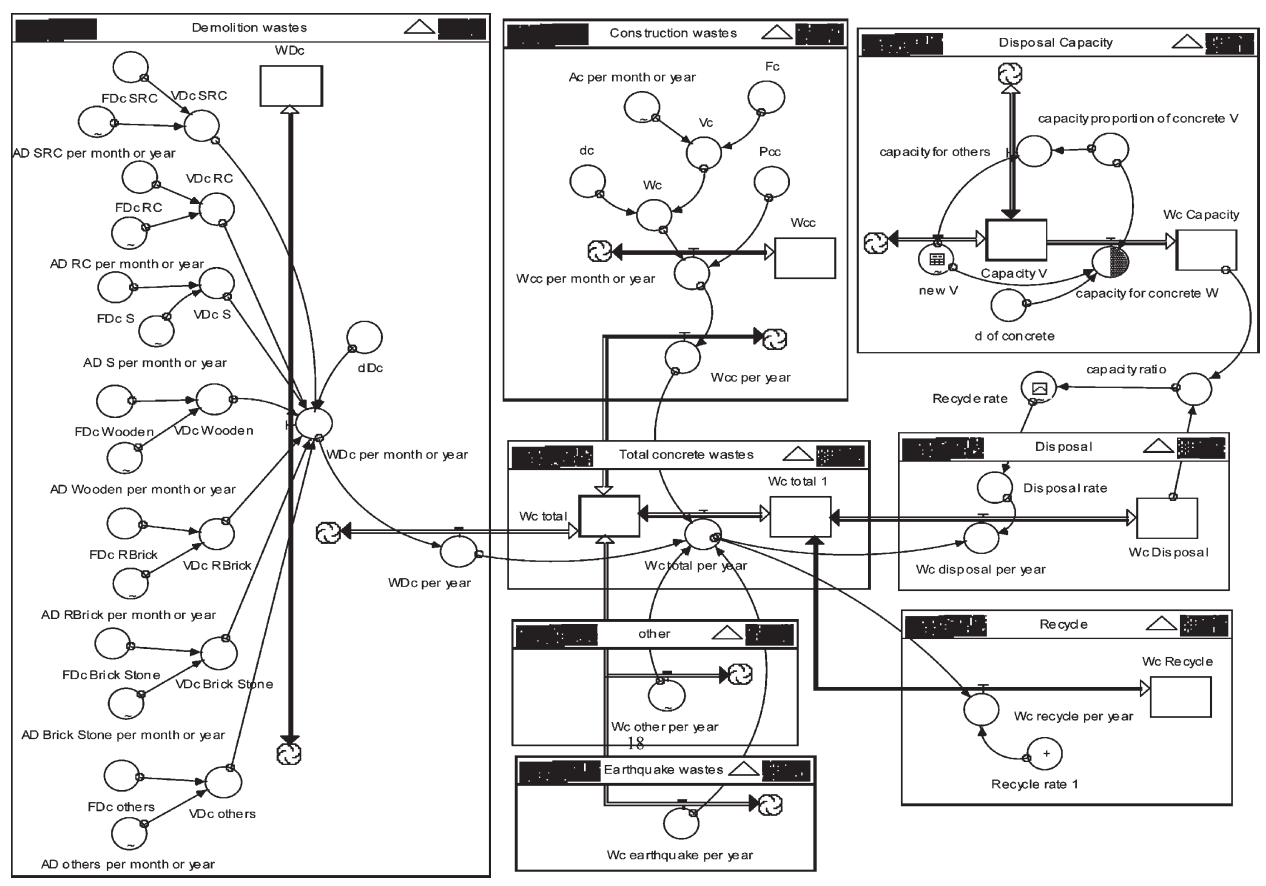

Fig. 5. Material flows model for estimating the waste concrete recycle target.

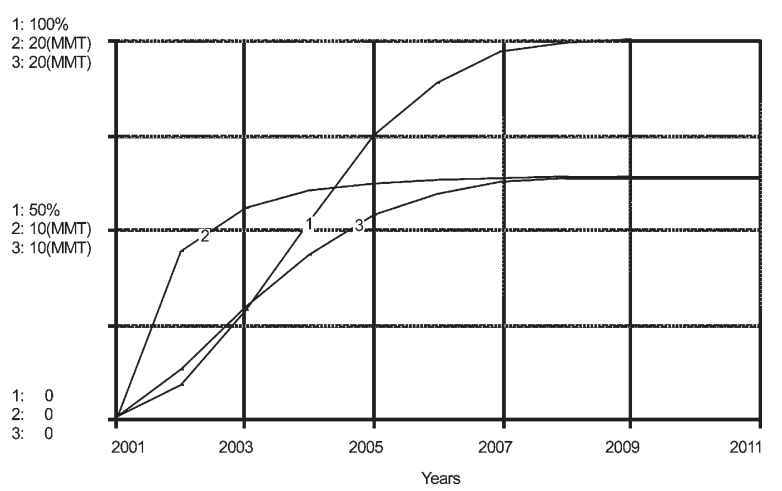

Based on our estimates the net economic benefits from recycling waste concrete could exceed US $\$ 3.5 \mathrm{M}$ using data from 2001 and exceed US\$11.7M according to our annual generation projections even without considering better recycling infrastructure and improving profit margins. The Taiwanese government and construction industry can promote efforts to establish a robust waste concrete market through financial incentives, government procurement, and the standardization of engineering specifications for its greater use.

Fig. 6. Projected waste concrete recycle rate targets in Taiwan from 2001-2011.

Table 3

Economic benefit assessment for waste concrete recycling in Taiwan, 2001 and from the 9/21/99 earthquake, see Table Notes in Appendix C

\begin{tabular}{|c|c|c|c|c|c|}
\hline & North area & Central area & South area & East area & 9/21/99 Earthquake \\
\hline Waste concrete output (tons/year) & 871,573 & 652,010 & 824,663 & 61,394 & $8,500,000$ \\
\hline $\begin{array}{l}\text { Project recycled aggregates output @ 32.5\% } \\
\text { (tons/year) }\end{array}$ & 283,261 & 211,903 & 268,015 & 19,953 & $2,762,500$ \\
\hline Cost of recycling and reuse (US\$/year) & $3,121,336$ & $2,335,022$ & $2,953,339$ & 219,867 & $30,440,771$ \\
\hline $\begin{array}{l}\text { Cost incurred from transporting waste concrete } \\
\text { to the final treatment site }\end{array}$ & $2,401,028$ & $1,796,171$ & $2,271,799$ & $169,128.50$ & $23,415,978$ \\
\hline Direct cost of using natural aggregate (US\$/year) & $2,483,023$ & $1,438,957$ & $1,561,578$ & $61,123,03$ & $18,759,125$ \\
\hline Economic benefits (US\$/year) & $1,762,715$ & 900,106 & 880,038 & 10,384 & $11,734,332$ \\
\hline $\begin{array}{l}\text { Economic benefits for recycling waste concrete } \\
\text { per metric ton (US\$) }\end{array}$ & 2.02 & 1.38 & 1.07 & 0.17 & 1.38 \\
\hline
\end{tabular}




\section{Appendix A: Data Notes}

Construction and demolition stage of building worklegal structure

Data sources described in text.

Construction stage of building work-illegal structure.

No data were found for illegal construction activity as no construction or use permits were on record. Thus this study estimates the waste generated from illegal construction to be under $5 \%$.

Demolition stage of building work-naturally destroyed structure.

Buildings that sustain damage in a minor disaster, but are not in danger of collapse still require a permit if they are to be demolished. Ordinarily, such cases are small in number. But the construction wastes of this kind generated in the aftermath of the 9/21/99 earthquake were substantial, approximately 15-20 MMT according to the Taiwan EPA. Assuming the proportion of concrete in demolition waste is $48.53 \%$, waste concrete from the 9/21/99 earthquake ranges between 7.25-9.67 MMT metric tons, averaging 8.5 MMT. The model factors in waste generated from the demolition of naturally destroyed structure and expresses it by Pulse function:

PULSE $\square \square$ volume $\square \square, \square$ first pulse $\square, \square$ interval

According to the observation data of Central Weather Bureau in the past 90 years, major quakes in the Richter scale of 7 or higher, like the 9/21/99 earthquake, might occur once every 30 years. Thus the model sets the interval at 30 years. The function was set as PULSE $8500000,1999,30 \square$.

Demolition stage of building work-illegal structure.

Some data concerning the demolition of illegal structures are available at the local government agency. But given that these data are incomplete, making estimation difficult, this study does not attempt to estimate waste concrete from this source.

\section{Demolition stage of building work-government requisition.}

Data on the structure and floor area of buildings to be demolished are generally available, but given that too many agencies are involved and the yearly implementation of the urban planning is not consistent, the annual demolition under government requisition varies significantly year by year. Thus this study does not include this source in the estimation.

Demolition stage of building work—illegal demolition.

No data were available, see (2) above.

Civil work.

Presently Taiwan has limited data on C\&D wastes generated from civil construction works. Demand for construction materials for civil construction activities in the early 1990 s was roughly $2 / 3$ the demand for building construction. Thus it is expected that concrete waste from civil construction may contribute a significant portion of national C\&D in Taiwan.

\section{Appendix B: Code for Waste Concrete Recycle Target Model}

Construction wastes

$$
\begin{aligned}
& \mathrm{Wcc}(\mathrm{t})=\mathrm{Wcc}(\mathrm{t}-\mathrm{dt})+(\mathrm{Wcc}-\mathrm{per}-\text { month-or- } \\
& \text { year } * \mathrm{dt} \\
& \text { INIT Wcc }=0 \\
& \text { INFLOWS: } \\
& \text { Wcc-per-month-or-year }=\text { Wc } * \text { Pcc } \\
& \text { Wcc-per-year = Wcc-per-month-or-year }
\end{aligned}
$$

INFLOW TO: Wc-total(IN SECTOR: Total concrete wastes)

$$
\begin{aligned}
& \mathrm{dc}=1.8 \\
& \mathrm{Fc}=0.1345 \\
& \mathrm{Pcc}=0.2117 \\
& \mathrm{Vc}=\mathrm{Ac}-\text { per-month-or-year } * \mathrm{Fc} \\
& \mathrm{Wc}=\mathrm{Vc} * \mathrm{dc} \\
& \text { Ac-per-month-or-year }=\text { GRAPH(TIME) }
\end{aligned}
$$

\section{Demolition wastes}

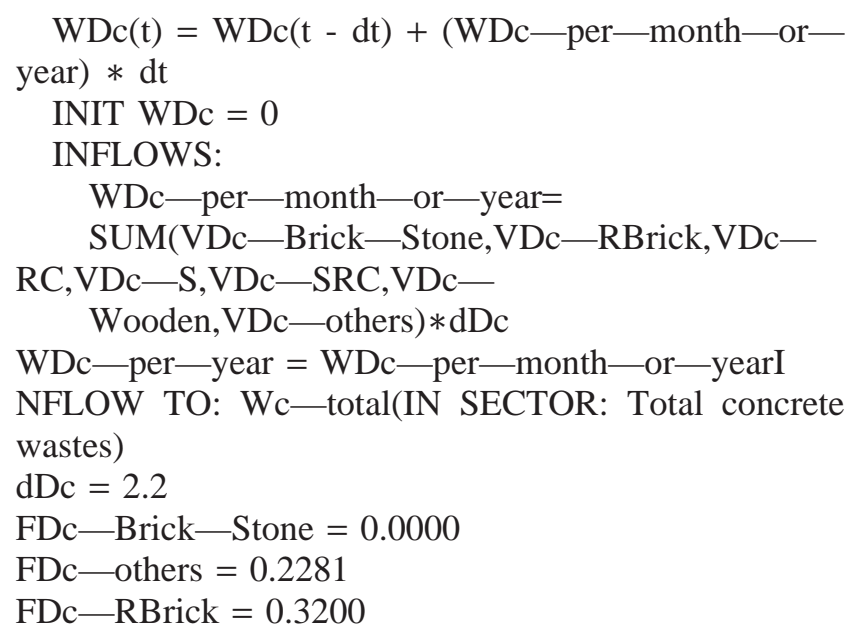




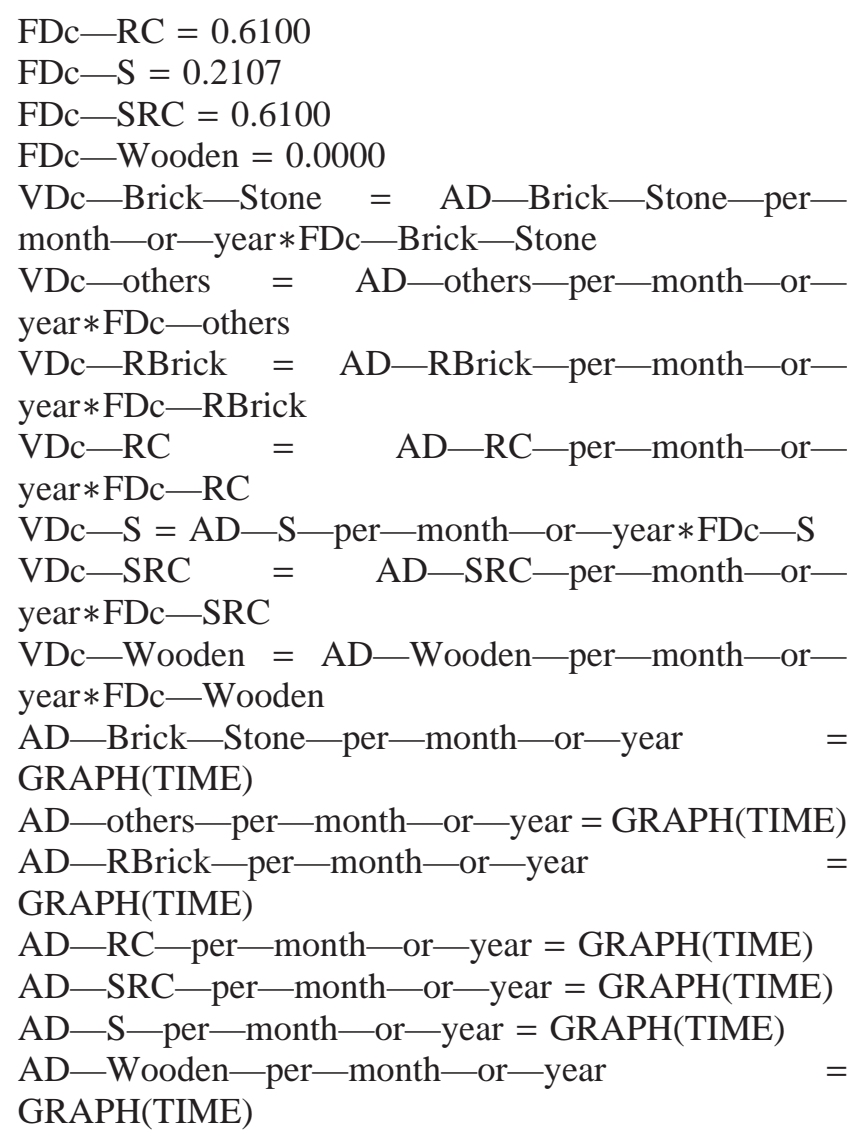

Disposal

$\mathrm{Wc}-\operatorname{Disposal}(\mathrm{t})=\mathrm{Wc}-\operatorname{Disposal}(\mathrm{t}-\mathrm{dt})+(\mathrm{Wc}-$ disposal-per-year) $* \mathrm{dt}$

INIT Wc-Disposal $=0$

INFLOWS:

Wc-disposal-per-year $=$ Wc-total - peryear*Disposal一rate

Disposal—rate $=1$-Recycle—rate

\section{Disposal capacity}

Capacity $-\mathrm{V}(\mathrm{t})=$ Capacity $-\mathrm{V}(\mathrm{t}-\mathrm{dt})+($ new $-\mathrm{V}-$ capacity—for-concrete-W - capacity—for-others) $* \mathrm{dt}$

INIT Capacity-V $=0$

INFLOWS: new-V = GRAPH(TIME)

OUTFLOWS:

capacity-for-concrete- $\mathrm{W}(\mathrm{o})=$ new $-\mathrm{V} *$ capacity-proportion-of-concrete- $\mathrm{V}$ capacity-for-others $=$ new $-\mathrm{V} *(1$-capacityproportion-of-concrete-V)

$\mathrm{Wc}-\operatorname{Capacity}(\mathrm{t})=\mathrm{Wc}-\operatorname{Capacity}(\mathrm{t}-\mathrm{dt})+($ capacityfor-concrete-W) $* \mathrm{dt}$

INIT Wc-Capacity $=0$

INFLOWS:

$\mathrm{d}-\mathrm{of}-$ concrete $=2.2$ capacity—proportion-of-concrete- $\mathrm{V}=0.1$

$\mathrm{d}$-of-concrete $=2.2$

\section{Earthquake wastes}

$\mathrm{Wc}$ - earthquake-per-year =

PULSE

$(8500000,88,30)$

INFLOW TO:

Wc-total(IN SECTOR: Total concrete wastes)

\section{Other}

Wc - other - per - year $=$ GRAPH $($ TIME $)$

INFLOW TO: Wc-total(IN SECTOR: Total concrete wastes)

Recycle

$\mathrm{Wc}-\operatorname{Recycle}(\mathrm{t})=\mathrm{Wc}-\operatorname{Recycle}(\mathrm{t}-\mathrm{dt})+(\mathrm{Wc}-\mathrm{recy}-$ cle-per-year) $* \mathrm{dt}$

INIT Wc-Recycle $=0$

INFLOWS:

Wc - recycle - per-year $=\mathrm{Wc}-$ total - per-year $*-$

Recycle-rate-1

Recycle - rate $-1=$ Recycle - rate

\section{Total concrete wastes}

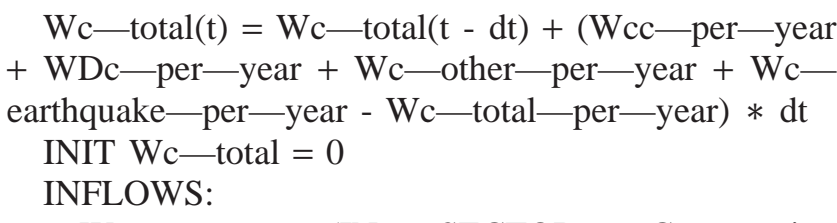
wastes) wastes)

WDc-per-year (IN SECTOR: Demolition

Wc-other-per-year(IN SECTOR: other)

Wc-earthquake-per-year (IN SECTOR: Earthquake wastes)

OUTFLOWS:

Wc-total-per-year $=$

SUM(Wcc-per-year,Wc-earthquake-peryear,Wc-other-per-year,WDc-p

er-year)

$\mathrm{Wc}-$ total-1 $(\mathrm{t})=\mathrm{Wc}-$ total-1 $(\mathrm{t}-\mathrm{dt})+(\mathrm{Wc}-$ total-per-year - Wc-recycle-per-year - Wc-disposal-per-year) $* \mathrm{dt}$

INIT Wc-total-1 $=0$

INFLOWS:

Wc-total-per-year $=$

SUM(Wcc-per-year,Wc-earthquake-peryear,Wc-other-per-year,WDc-p

er-year)

OUTFLOWS: 
Wc-recycle-per-year(IN SECTOR: Recycle)

Wc_disposal—per-year(IN SECTOR: Disposal)

Not in a sector

capacity—ratio $=\operatorname{IF}($ TIME $>=91) \operatorname{THEN}(\mathrm{Wc}-$

Disposal/Wc_Capacity)ELSE(0)

Recycle—rate $=$ GRAPH (capacity-ratio)

\section{Appendix C: Table notes}

1. NT\$/ US\$ $=33$

2. The cost of waste concrete transport to final treatment site, $\mathrm{C}_{1}\left(\mathrm{NT}\right.$ dollars $\left./ \mathrm{m}^{3}\right)$ is $\mathrm{C}_{1}=\mathrm{C}_{\mathrm{d}}+\mathrm{C}_{\mathrm{t}}$

Where: $C_{d}=$ the average regional landfill tipping fee (NT dollars $/ \mathrm{m}^{3}$ ) and $\mathrm{C}_{\mathrm{t}}=$ the average transport cost for a distance of $30 \mathrm{~km}\left(\mathrm{NT}\right.$ dollars $\left./ \mathrm{m}^{3}\right) \mathrm{C}_{1}=200$ (NT dollars $/ \mathrm{m}^{3}$ )

3. The recycled and treated cost of waste concrete, $\mathrm{C}_{2}$ (NTdollars $/ \mathrm{m}^{3}$ ) is $\mathrm{C}_{2}=\mathrm{C}_{\mathrm{r}}+\mathrm{C}_{\mathrm{t}}$

Where: $\mathrm{C}_{\mathrm{r}}=$ the average processing cost for waste concrete $\left(\mathrm{NT}\right.$ dollars $\left./ \mathrm{m}^{3}\right) \mathrm{C}_{2}=260\left(\mathrm{NT}\right.$ dollars $\left./ \mathrm{m}^{3}\right)$

4. The cost of using natural aggregates, $\mathrm{C}_{3}$ (NT dollars $\left./ \mathrm{m}^{3}\right)$ is $\mathrm{C}_{3}=\mathrm{C}_{\mathrm{n}}+\mathrm{C}_{\mathrm{t}}$

Where: $C_{n}=$ the current average prices of natural aggregates by region (NT dollars $/ \mathrm{m}^{3}$ ) $\mathrm{C}_{3}=$ North636; Central-493; South-423; East-222 (NT dollars $/ \mathrm{m}^{3}$ )

5. Economic Benefit $=\left(\mathrm{W}_{\text {concrete }} / \mathrm{d}_{\text {concrete }}\right) \times \mathrm{C}_{1}+($ $\left.\left.\mathrm{W}_{\text {concrete }} / \mathrm{d}_{\text {concrete }}\right) \times \mathrm{r} \times \mathrm{C}_{3}\right]-\left[\left(\mathrm{W}_{\text {concrete }} / \mathrm{d}_{\text {concrete }}\right) \times\right.$ $\left.\mathrm{C}_{2}+\left(\mathrm{W}_{\text {concrete }} / \mathrm{d}_{\text {concrete }}\right) \times \mathrm{r} \times \mathrm{C}_{\mathrm{t}}\right]$ (NT dollars)

Where: $\mathrm{W}_{\text {concrete }}$ is the total production weight of waste concrete by region in tons $d_{\text {concrete }}$ is the specific gravity of waste concrete is average $2.2\left(\right.$ tons $\left./ \mathrm{m}^{3}\right) \mathrm{r}$ is the production rate of recovered aggregate (the ratio of recovered aggregate production and recycle waste concrete). We assume a production rate of $32.5 \%$.

6. The North area includes: Taipei city, Keelung city, Hsinchu city, Taipei county, Taoyuan county, Hsinchu county, Yilan county and Lianchiang county. The Central area includes: Taichung city, Mouli county,
Taichung county, Chunghwa county, Nantou county, and Yunlin county. The South area includes: Kaohsiung city, Chiayi city, Tainan city, Chiayi county, Tainan county, Kaohsiung county, Pingtung county, Penghu county, and Kinmen county. The East area includes: Hualien county and Taitung county.

\section{References}

Architecture and Building Research Institute (ABRI), Taiwan Ministry of Interior. 1998a. A Study of Survey Structure of Construction Demolished Pollution \& Wastes, pp. 20-45.

Architecture and Building Research Institute (ABRI), Taiwan Ministry of Interior. 1998b. A Survey of Pollution \& Wastes in Construction Processes, pp. 45-62.

Architecture and Building Research Institute (ABRI), Taiwan Ministry of Interior. 1999. A Study of Check System \& Minimization for Construction Wastes in Taiwan, pp. 65-78.

Bureau of Mines, Taiwan Ministry of Economics Affairs (MOEA). 1999. A report on aggregates substitution, pp. 59-72.

Architecture and Building Research Institute (ABRI), Taiwan Ministry of Interior. 2000. Developing Reuse Technology for Construction Concrete Waste, pp. 60-68.

Chen C, 1998 Marine Sand for Sustainable Aggregate Supply, Marine Resource Conservation-MRC (Chile) Bulletin, October.

Chen, Z.J., 1996. Suitability Analysis \& Construction Technology on Construction Materials. The Zhan Press, Taipei.

Construction and Planning Administration (CPA), Taiwan Ministry of Interior. 2001. An Annual Report of Construction in Taiwan.

Hsiao, T.Y., Yu, Y.H., Wernick, I.K., 2001. A note on material flows of construction aggregates in Taiwan. Resources Policy 27 (2), $135-137$.

Kelly, T., 1998. Crushed cement concrete substitution for construction aggregates: a materials flow analysis. Washington, DC: United States Geological Survey Circular No. 1177.

Poon, C.S., 1997. Management and recycling of demolition waste in Hong Kong. Waste Management \& Research 15, 561-572.

Wei, K.S., Tan, L.P. 1999. Non-ferric Economic Minerals in Taiwan, Vol. 2, Central Geological Survey in Taiwan, Ministry of Economic Affairs (MOEA), p. 22.

Wernick I.K., Ausubel J.H., 1997. Industrial Ecology: Some Directions for Research. Report commissioned by the Energy and Environmental Systems Division, Lawrence Livermore National Laboratory, US Department of Energy. Available at http://phe.rockefeller.edu (online publications).

Wilburn, D.R., Goonan, T.G., 1998. Aggregates from natural and recycled sources economic assessments for construction applications: a materials flow analysis. Washington, DC: United States Geological Survey Circular No. 1176. 